NBER WORKING PAPER SFRIGS

THE FISCAL FRAMFWORK OF MONETARY POLICY

Martin Feldstein

Working Paper No. 966

NATIONAL BUREAU OF ECONOMIC RESEARCH 1050 Massachusetts Avenue

Cambridge MA 02138

August 1982

The research reported here is part of the NBER's research program in Taxation. Any opinions expressed are those of the author and not those of the National Bureau of Economic Research. 


\section{ABSTRACT}

This paper illustrates the importance of the fiscal framework for monetary analysis by discussing three separate issues. I begin by examining how the fiscal framework changes the macroeconomic equilibrium associated with different steady state rates of money growth. This includes a summary of research that I have presented elsewhere and comments on several additional aspects of the way in which the fiscal structure destroys the neutrality of monetary policy.

The second section deals with the short-run impact of changes in monetary policy. Here again the fiscal structure complicates the economy's response to monetary policy.

The final section looks at the effect of the fiscal structure on the central bank's choice of monetary policies. Because fiscal structures affect the costs and benefits of monetary policies, they are likely to influence the policies adopted.

Martin Feldstein National Bureau of Economic Research 1050 Massachusetts Avenue Cambridge, MA 02138

(617) 868-3905 


\title{
The Fiscal Framework of Monetary Policy
}

\author{
Martin Feldstein*
}

I am very honored by your invitation to present this lecture. I

will use this occasion to discuss a subject that has been an important focus of my own work in the past decade and that lies at the boundary of macroeconomics and public finance: the fiscal framework of monetary policy.

The failure to deal explicitly with the fiscal framework of monetary policy is a serious shortcoming of modern monetary theory. My purpose in this lecture is to advocate that the theory and practice of monetary economics devote more attention to the ways in which the tax structure influences the impact of monetary policy

I find it very strange that virtually all studies of monetary policy, empirical as well as theoretical, ignore the system of tax rules within which monetary policy has its influence. Ignoring taxes was no doubt justifiable when tax rates were very low. Fifty years ago, most individuals paid no income tax at all and the median tax rate among those who did pay tax was less than 5 percent. By contrast, in the 1970s individuals could pay tax on investment income at rates up to 70 percent and taxes took more than two-thirds of the real income of nonfinancial corporate capital.

A particularly important aspect of the tax system is its failure to distinguish between nominal and real magnitudes. Monetary policies that alter the price level or the rate of inflation therefore change effective tax rates and alter the incentives to engage in different types of activities. Thus, even if the conditions required for the neutrality or superneutrality of money would

*Professor of Economics, Harvard University, and President of the National Bureau of Economic Research. This paper was presented as the Distinguished Lecture at the 1982 annual meeting of the Western Economic Society, July 16, 1982. 
be satisfied in the absence of taxes, the fiscal framework would effectively destroy both neutrality and superneutrality.

To avoid misunderstanding, let me say at the outset that I am not arguing that a full description of an economy's fiscal structure should be part of every study of monetary economics. Including even a rudimentary description of the fiscal framework would obviously increase the complexity of any study In some cases, such complexity can obscure the particular subject of interest without changing anything of fundamental importance. I do believe, however, that those who would ignore the fiscal framework must bear the burden of arguing that such simplification is not misleading. Froirical studies that ignore taxes are particularly suspect.

To illustrate the importance of the fiscal framework for monetary analysis, I will discuss three separate issues. I will begin by examining how the fiscal framework changes the macroeconomic equilibrium associated with different steady state rates of money growth. This will include a summary of research that I have presented elsewher ${ }^{l}$ and comments on several additional aspects of the way in which the fiscal structure destroys the neutrality of monetary policy.

The second section of remarks will deal with the short-run impact of changes in monetary policy. Here again the fiscal structure complicates the economy's response to monetary policy.

The final section looks at the effect of the fiscal structure on the central bank's choice of monetary policies. Because fiscal structures affect the costs and benefits of monetary policies, they are likely to influence the policies adopted.

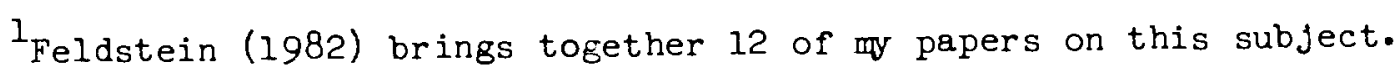




\section{Tax Rules and Monetary Equilibrium}

An increase in the stock of money induces a corresponding increase in the level of prices. Similarly, a permanent increase in the rate of growth of the money stock induces a corresponding increase in the rate of inflation. These basic steady-state properties follow directly from the proportionality of money demand to the price level and are not affected by the economy's fiscal structure. However, the interaction of tax rules and price inflation does change the equilibrium of the real economy in a wide variety of ways. This section first comments briefly on the non-neutrality of one-time changes in the money stock and then discusses in more detail the effects of sustained increases in the growth of money.

The most widely understood effect of inflation on tax liabilities is the result of the progressive structure of tax rates. A general rise in the level of prices and incomes shifts taxpayers into higher tax brackets and thereby raises the overall effective tax rate. With the existing structure of U.S. tax rates, a 10 percent increase in money incomes raises tax revenue by 16 percent, thereby raising the effective tax rate by about 6 percent. Moreover, the shift of individuals to higher tax brackets raises marginal tax rates and thereby lowers the net of tax wage rate and the net of tax rate of interest. Thus, a one-time increase in the stock of money is far from neutral in our economy.

To simplify the discussion in the remainder of this paper, I will

ignore the bracket creep effect of the progressive structure of taxes. I will assume instead that the tax brackets are fully indexed. I will, however, comment on the implication of the fact that individuals do face different tax rates and, in the third section, I will discuss the effect of nonindexation on the determination of monetary policy. 
Even if tax brackets are fully indexed, the tax system is very sensitive to inflation because it fails to distinguish between real capital income and nominal capital income. Recall for comparison what happens in an economy without taxes when a permanent $r i s e$ in the growth rate of money causes an increase in the steady state inflation rate. If the demand for money is completely interest inelastic, the nominal rate of interest rises by the rate of inflation. This leaves the real rate of interest and all other real magnitudes in the economy unchanged. This is the superneutrality property that we associate with Irving Fisher. As Tobin (1965) and Mundell (1963) have emphasized, this superneutrality is lost if the demand for money is interest sensitive. The rise in the nominal interest rate then causes a reduction in the demand for money and a substitution of real capital for money in individual portfolios. The resulting capital deepening in production reduces the real rate of interest. Although this effect is theoretically correct, it is likely to be very small in practice. Since M, which is a broader measure of money than is appropriate for the Mundell-Tobin theory, is only five percent of total private wealth, the scope for portfolio substitution is extremely limited. I shall therefore ignore this effect and assume a completely inelastic demand for money in order to contrast the tax effects with the superneutrality that would otherwise characterize equilibrium.

One of the most important features of the U.S. tax system is that taxable income reflects nominal interest receipts and expenses instead of real interest receipts and expenses. Before looking at other complexities of the tax system, it is helpful to consider an economy in which taxable income is correctly measured in all respects except that nominal rather than real interest 
receipts and expenditures are included. ${ }^{1}$ As sume for the moment that savings are not affected by the rate of return that savers receive and that all saving is absorbed in private capital formation. This is sufficient to insure that the steady state capital intensity remains constant and therefore that the real marginal product of capital, $f^{\prime}$, is unchanged.

The equilibrium condition for a competitive firm is that the real netof-tax marginal product of capital, $(1-\tau) f^{\prime}$ where $\tau$ is the corporate tax rate, is equal to the real net-of-tax rate of interest. If the nominal rate of interest is $i$, the net-of-tax nominal rate is $(1-\tau) i$ and the net of tax real rate is $(1-\tau) i-\pi$, where $\pi$ is the rate of inflation. It is important to note that the tax law permits deduction of the nominal interest rate so that the tax deduction is $\tau i$. The equilibrium condition is thus

$$
(1-\tau) f^{\prime}=(1-\tau) i-\pi .
$$

Solving for the rate of interest yields:

$$
i=f^{\prime}+\frac{\pi}{1-\tau}
$$

The individual lender who provides capital to the firm must, of course, pay tax on the full nominal interest rate. The real net return received by the individual, $r_{N}$, is thus equal to the real interest rate, $i-\pi$, minus the tax on the nominal interest rate, $\theta i$, where $\theta$ is the marginal rate of personal income tax. Thus,

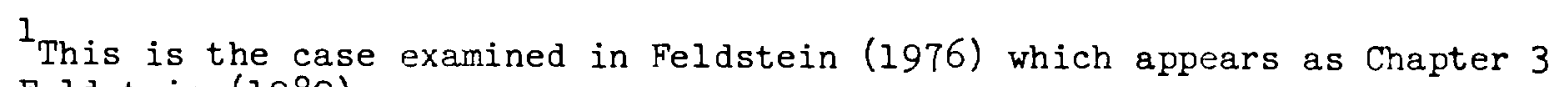
of Feldstein (1982). 


$$
r_{N}=(1-\theta) i-\pi .
$$

Substituting equation 2 for $i$ yields

$$
r_{N}=(1-\theta) f^{\prime}+\frac{\tau-\theta}{1-\tau} \pi
$$

The real net interest rate received by the individual lender is thus affected by inflation unless the corporate tax rate and the individual tax rate are equal, i.e., unless the benefit that corporations get from deducting the full nominal interest payment is offset exactly by the penalty to individuals that arises from paying tax on the full nominal interest receipt.

Since individuals have different personal tax rates, they will be affected differently by inflation. Equation 4 shows that individuals with low marginal tax rates $(\theta<\tau)$ and tax exempt investors like universities and pension funds $(\theta=0)$ will benefit from inflation while investors with high marginal tax rates $(\theta>\tau)$ will find that inflation lowers their real rate of return. If we now drop the assumption that saving is not sensitive to the real net rate of return that savers receive, we see that a change in the rate of monetary expansion will lead to a change in capital intensity. To see the importance of this, consider for a moment the extreme case in which all personal tax rates are equal and the supply of saving is infinitely elastic at the real net interest rate $(1-\theta) f^{\prime} 0$ where $f^{\prime}{ }_{0}$ is the marginal product of capital in the absence of inflation. With inflation at rate $\pi$ the marginal product of capital must adjust to a level $f^{\prime}{ }_{1}$ that maintains the same real net return to savers:

$$
(1-\theta) f^{\prime} 0=(1-\theta) f^{\prime}{ }_{1}+\frac{\tau-\theta}{1-\tau} \pi,
$$


or,

$$
f_{1}^{\prime}=f^{\prime} 0-\frac{\tau-\theta}{(1-\tau)(1-\theta)} \pi .
$$

If $\tau$ is greater than $\theta$, inflation reduces the equilibrium marginal product of capital and therefore increases the capital intensity of the econom. Although these simple calculations are sufficient to illustrate the important non-neutrality of a sustained (and therefore anticipated) monetary expansion, let me warn you not to take the specific results seriously because we have not yet considered other important ways in which tax rules affect the economy's monetary equilibrium. Among the most significant of these is the tax treatment of depreciation and inventory costs.

Existing tax law bases depreciation allowances on the original or "historic" cost of an asset with no adjustment for the increase in the price level since the asset was acquired. When the price level increases, the depreciation component of costs is understated. Taxable profits are therefore overstated and the effective tax rate rises. Similarly, the use of the firstin-first-out (FIFO) method of inventory valuation also causes an understatement of costs when there is inflation and therefore an overstatement of taxable income. These effects are very large; a few years ago, Larry Summers and I (Feldstein and Summers, 1979) calculated that the excess taxes due to the use of historic cost depreciation and inflated inventory profits accounted for 45 percent of the taxes paid by nonfinancial corporations.

If we approximate this extra tax burden per unit of capital as proportional to the rate of inflation, the real net-of-tax rate of return to the firm becomes $(1-\tau) f^{\prime}-\lambda \pi$ where $\lambda$ measures the effect of inflation on net-of-tax profi- 
tability. Empirical calculations suggest that under the tax law prevailing before 1981, $\lambda$ was approximately one-fourth (see the appendix to chapter 11 in Feldstein, 1982.) The firm's equilibrium condition requires equating the real net-of-tax return to the firm to the real net-of-tax rate of interest:

$$
(1-\tau) f^{\prime}-\lambda \pi=(1-\tau) i-\pi
$$

Thus the nominal rate of interest is

$$
i=f^{\prime}+\frac{1-\lambda}{1-\tau} \pi
$$

and the real rate of interest is

$$
i-\pi=f^{\prime}+\frac{\tau-\lambda}{1-\tau} \pi \text {. }
$$

Equation 9 shows that inflation raises the real rate of interest if $\tau>\lambda$ and lowers it if $\tau<\lambda$. The explanation of this is simple: the real rate of interest that firms can pay with a given marginal product of capital is depressed by inflation to the extent that it induces extra taxes because of historic cost depreciation and FIFO inventory accounting (hence the negative $\lambda$ term) but is increased by inflation because nominal interest payments are deductible in the calculation of taxable interest (the positive effect of $\tau$ ). Equation 8 shows that if $\lambda$ and $\tau$ were equal, the nominal interest rate would rise roughly point-for-point with the inflation rate. Thus Irving Fisher's equilibrium relation could be true in an economy with distortionary taxes, but because of numerically offsetting factors rather than because of any inherent tendency toward a constant real rate of return.

It is important, moreover, to note that a constant real rate of interest means that the real net-of-tax rate of interest received by taxable lenders depends on the rate of inflation: 


$$
\begin{aligned}
r_{N} & =(1-\theta) i-\pi \\
& =(1-\theta) f^{\prime}+\frac{(1-\theta)(1-\lambda)}{1-\tau} \pi-\pi \\
& =(1-\theta) f^{\prime}+\frac{\tau-\theta-(1-\theta) \lambda}{1-\tau} \pi_{0}
\end{aligned}
$$

To see how large this effect is, note that if $\tau=\theta$, the real net rate of interest falls by $\lambda$ per percentage point of inflation; if we take asa a reasonable approximation that the marginal product of capital is $f^{\prime}=.12$, that $\theta=\tau=0.5$ and that $\lambda=0.25$, a 12 percent rate of inflation reduces the real net return in half, from six percent to three percent.

The fall in the net return caused by inflation implies that a sustained monetary expansion will change the equilibrium capital intensity and therefore the marginal product of capital. Thus even when $\tau=\lambda$ the full general equilibrium response to inflation contradicts Fisher's prediction that the equilibrium nominal interest rate rises by the rate of inflation.

A further word of caution. The results that I have derived assume that firms are 100 percent debt financed at the margin ${ }^{1}$. If firms are 100 percent equity financed or use a mixture of debt and equity (Feldstein, Green and Sheshinski, 1978) the quantitative results can be quite different. For my purpose today, however, it is not necessary to derive definitive results. It is sufficient to establish that, even if money demand is completely inelastic,

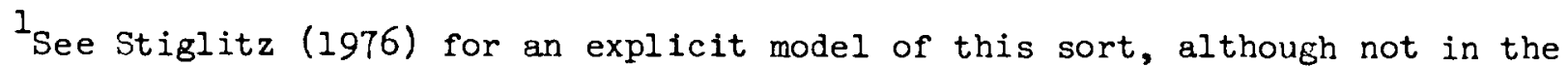
context of inflation. For a more general model of the debt - equity choice, see Auerbach (1982). 
changes in the steady-state rate of money growth are far from neutral in their effect on the real equilibrium of the economy.

Lest this seem like a lot of effort to demolish an intellectual straw man, let me remind you that, except for Tobin-Mundell liquidity effects, the long-run dichotomy between the money growth rate and the real economy is assumed in virtually all of the best work in monetary theory, including such outstanding examples as Tobin (1963) and Sargent $(1980)^{1}$. Even more significant are the statistical studies like Barro (1977) and Fama (1975) that take the neutrality of anticipated money growth as a theoretically justified null hypothesis. Similarly, when Schiller (1980) investigated whether Federal Reserve policy could alter the real interest rate, his focus was too narrow. By altering the rate of inflation, the Fed alters the difference between the net-of-tax real profitability of investment and the net-of-tax real cost of funds.

The adverse effect of inflation on the profitability of business investments causes a shift of the capital stock away from plant and equipment and into owner-occupied housing (Feldstein, 1982, chapter 6). In fact, during the 1970 s the share of residential construction in total net investment increased and the real value of single family homes rose sharply because the relative stock of housing had not yet increased to its new equilibrium level (Poterba, 1980).

A similar disequilibrium response was also reflected in the behavior of share prices. In the very long run, share prices must rise at the same rate as the price level in general. In the short run, however, an increase in the

${ }^{1}$ An interesting counterexample is a very recent paper by Modigliani and Papademos (1982). 
equilibrium inflation rate depresses the expected after-tax return on equity capital relative to other portfolio investments and therefore reduces the market price of corporate shares (Feldstein, 1982, Chapters 10 and 11). 1 This is a temporary condition which is reversed gradually as a reduction in the relative size of the corporate capital stock permits the real pretax rate of return to rise. ${ }^{2}$

To understand the full interaction of inflation and the tax system, it is necessary to look beyond the basic tax rules affecting interest payments, depreciation, capital gains and inventories. The tax code contains a miad of special provisions affecting different types of capital income that may be influenced by inflation: there are special rules for banks, insurance companies, timber, oil and gas, farmers, utilities, etc. I am certain that there are many such influences of which I am unaware. To illustrate the importance of such special features, I will describe the tax rules that apply to the portfolio income of life insurance companies. ${ }^{3}$

In the United States, individuals pay life insurance premiums with after-tax dollars and the insurance benefits subsequently received are not part of taxable income. If the insurance companies were not subject to tax on their portfolio income, savings in the form of life insurance would effectively be treated on a consumption tax basis, i.e., there would be no tax on the interest earned on this form of saving. This was almost the situation immediately after 1959 when the current special income tax rules for insurance companies were enacted. That law provides that an insurance company would pay no tax on its

$1_{\text {Share prices are also depressed by the fact that inflation produces }}$ nominal capital gains that are subject to tax when the stock is sold.

2 See Summers (1982) for an explicit model of the adjustinent process in a rational expectations general equilibrium model.

2 This discussion draws on Feldstein and Warshawsky (1982). 
portfolio income, savings in the form of life insurance would effectively be treated on a consumption tax basis, i.e., there would be no tax on the interest earned on this form of saving. This was almost the situation immediately after 1959 when the current special income tax rules for insurance companies was enacted. That law provides that an insurance company would pay no tax on its portfolio income if that income was just enough to provide the nominal rate of return that it had promised to its policyholders. The promised rate, which is controlled by the state insurance commissioners, changes very little and is still less than five percent.

If an insurance company earns more than the promised rate, it must pay tax at the corporate rate on a portion of its capital income. That portion is determined by an archane rule, the Menge formula, that provides that the taxed portion is ten times the difference between the rate of return on the company's portfolio and its promised rate of return. Thus, if a company earns 6 percent on its protfolio and has a promised rate of 4 percent, it pays tax at the corporate rate on 20 percent of its portfolio income; equivalently, it pays tax on all its portfolio income at 20 percent of the corporate rate or about a 9 percent tax rate.

As long as the interest rate on the bonds held by insurance companies was close to the low promised rate set by the regulators, saving in the form of life insurance was virtually tax free. This not only encouraged life insurance as a form of saving but also, by providing a tax free vehicle for life cycle saving, encouraged saving in general.

Consider now what happens as inflation raises the rate of interest. With a 10 percent inflation rate and a 14 percent bond interest rate, the Menge formula indicates that the insurance company would be taxed at 100 percent of 
the corporate tax rate on its total portfolio income. Inflation means that life insurance is no longer an essentially untaxed way to do life cycle saving. Moreover, saving in the form of life insurance would have a lower after-tax yield than direct investment in the same bond portfolio for anyone whose personal tax rate was less than the corporate tax rate.

The special tax rules affecting life insurance thus are another way in which an inflationary monetary policy reduces the rate of capital accumulation. I think the problem of life insurance taxation is also a good indication of the complexity of adjusting the tax laws to eliminate the effect of changes in the rate of inflation. Although fifteen years of inflation has been long enough to reduce substantially the rate of life insurance saving, it has not been long enough for the political process to find a way to remedy these problems. Until now, I have limited my analysis to the effects of monetary policy, in a closed economy. When the broader perspective of an open economy is considered, the interaction between inflation and tax rules also influences international capital flows and therefore international trade. In an open economy without taxes, a steady state increase in inflation in the home country would cause its nominal interest rate to rise by the increase in the rate of inflation. Because of purchasing power parity, the value of its currency would depreciate at that same rate relative to the currencies of all other countries. A foreign lender who buys bonds of the home country would thus receive the same rate of interest net of exchange loss as he had before the increase in inflation. Inflation provides no incentive for international capital flows. To see one way in which taxes might change the analysis, I will follow Hartman (1979) and consider an economy in which the only imperfection in the tax system is to include nominal interest instead of real interest. With that tax 
rule, the nominal interest rate in the home country would rise not by the increase in the rate of inflation but by that rate divided by one minus the corporate tax rate $(\mathrm{di} / \mathrm{d} \pi=1 /(1-\tau))$. With a corporate tax rate of one-half, the nominal interest rate would rise by twice the increase in inflation. Purchasing power parity would still imply that in equilibrium the currency depreciated at the rate of inflation. The rate of interest to the foreign lender who buys home country bonds, net of currency depreciation, thus rises by the increase in the rate of inflation.

This is clearly not an equilibrium situation. Capital will flow into the home country until the rate of interest net of currency depreciation is the same there as in the rest of the world. Capital flow achieves equilibrium by increasing the capital intensity in the home country (thus driving down the real rate of retur $n$ ) and lowering the capital intensity in the rest of the world (thereby raising the real rate of return elsewhere). The equilibrium occurs when the difference between the marginal products of capital at home and abroad is equal to the rate of inflation.

Although this is an oversimplified picture of taxes and international capital movements, it is sufficient to show how taxes cause an inflationary monetary expansion to have real effects on the distribution of the world capital stock and therefore on capital flows and trade patterns.

Before leaving the framework of the steady-state behavior of the economy, I want to comment briefly on the implication of the fiscal framework for the theory of optimal inflation and the optimal quantity of money. Milton Friedman (1969) pointed out that a negative rate of inflation equal to the real rate of interest would make the nominal interest rate zero and would thereby reduce the opportunity cost of holding money to its zero cost of supply. Any 
higher rate of inflation would in effect imply a tax on holding money balances and would thereby move the economy away from an efficient equilibrium. Friedman's negative rate of inflation would of course require a continuing decline in the money stock which would in turn require a continuing surplus in the government budget. Friedman's condition would thus be optimal only if there were a lump sum tax to produce the necessary revenue without introducing any distortion. Phelps (1973) subsequently noted that without lump sum taxes it would be optimal to have a higher rate of inflation since the net money creation (or the reduced rate of decline of the money stock) would permit a reduction in other distorting taxes.

The optimal rate of inflation and the optimal quantity of money become a more complex problem when we recognize that inflation distorts the taxation of capital income. Because of the fiscal structure, a higher rate of inflation has the advantage of producing tax revenue (if the effects of understated depreciation and inventory costs outweigh the deduction of nominal interest income) and of shifting portfolios from capital to money (thereby offsetting the usual bias against holding non-interest-bearing money balances). At the same time, of course, the interaction of inflation and the fiscal structure reduces the incentive to save and distorts the allocation of capital among different uses. The optimal steady state rate of inflation can only be established by a quantitative evaluation of all these effects.

\section{Tax Rules and Monetary Transition}

The fiscal structure of an economy affects not only the steady state equilibrium associated with any level and rate of growth of the money stock but also influences the character of the transition from one steady rate of money 
growth to another. Since the evolution of expectations about monetary policy are a critical determinant of the transition process but are not central to understanding the influence of tax rules, I will assume that expectations adjust immediately to the new reality. To be specific, I will consider the case in which the money stock has been growing at 10 percent a year for a long period of time when the central bank announces that henceforth the money growth rate will be only 4 percent. Everyone immediately and correctly adjusts his expected rate of money growth to 4 percent for the indefinite future.

Consider first what would happen in an econom with no taxes. The 6 percentage point decline in the money growth rate implies a 6 percentage point decline in the steady state inflation rate. To keep the real interest rate unchanged, the nominal interest rate must also decline by six percentage points. This "superneutral" response to the decline in money growth is possible only if the demand for money is completely insensitive to the interest rate. With any interest elasticity, the lower nominal interest rate causes an increase in the demand for money. The increased money demand means a lower capital intensity and a higher real rate of interest. As I noted earlier, however, the very small size of the non-interest-bearing money stock relative to the capital stock makes this Tobin-Mundell effect on capital intensity and on the equilibrium real interest rate very small.

Although the interest sensitivity of money demand has only a small effect on steady state equilibrium, it can have a powerful effect on the transition process. To satisfy the increased demand for real money balances at the lower nominal interest rate, the price level must decline immediately. Thus the announcement of a lower rate of growth of money implies an equal decline in the 
nominal interest rate only if the price level can drop immediately by enough to reduce the demand for nominal money balances to the available supply.

In reality, prices are not completely flexible downward and the price level does not fall fast enough to permit the real interest rate to remain unchanged. Instead, the nominal interest rate must remain high to balance the supply and demand for money. The result is a rise in the real rate of interest and this high real rate induces a decline in economic activity. The lower level of economic activity and the decline in inflation that it causes both reduce the demand for money but not by enough to permit an immediate return of the real interest rate to its natural level. As long as the real interest rate is above its natural rate, there will be slack in the economy and therefore downward pressure on inflation and interest rates. The high real rate is thus eventually self-correcting.

The slow fall in the short-term rate keeps the long term rate above its eventual equilibrium value even if expectations about declining inflation are held with certainty. This high level of the long-term rate follows directly from the fact that, in the absence of uncertainty, the long rate is an average of the future short rates. Thus if the short rate is expected to decline from 13 percent to 7 percent at the rate of one percent a year and then to remain at 7 percent, a new 10-year bond will have a yield to maturity of 9 percent. The increase in real rates of interest during the transition period implies that a decline in the rate of money growth is far from neutral even in a taxless econony. The presence of a tax system complicates and exacerbates this non-neutrality.

As I emphasized earlier, because the tax system is not indexed, the rate of money growth affects the real rate of interest and the real after-tax 
profitability of different activities. A change in the rate of money growth therefore induces a shift of resources among different industries. In particular, because the interaction of taxes and inflation penalizes investment in depreciable plant and equipment relative to investment in owner-occupied housing, a permanent decrease in the rate of money growth induces a shift of resources out of housing and into plant and equipment investment. Similarly, because inflation reduces the after-tax yield on saving, a decrease in the rate of money growth induces a shift from consumption to saving.

Although the intersectoral shift of resources induced by a change in money growth could in principle occur without any unemployment, the reduced demand for the products of some sectors is likely to involve some unemployment before the workers in those sectors find employment elsewhere. Unemployment would arise naturally in this process if there is an advantage to devoting full time to searching for a new job. The availability of unemployment benefits that drastically reduce the opportunity cost of remaining unemployed tends to raise the reservation wage of those who must change jobs and therefore to increase significantly the duration of unemployment. ${ }^{1}$

It is interesting to contrast this view of the way in which a reduction in the money growth rate causes unemployment with the theory developed many years ago by Freidrich Hayek. Hayek also argued that a decline in inflation would cause a downturn in economic activity because the lower rate of inflation would cause some sectors to contract. More specifically, however, Hayek believed that business investment would expand during an inflationary period because bank

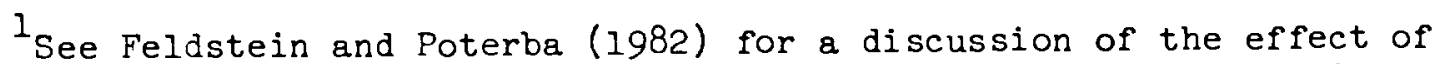
unemployment insurance on reservation wages and the average duration of unemployment.
} 
credit looked cheap and profits were artificially increased by the fact that price increases temporarily exceeded wage increases. The essence of Hayek's argument was therefore that inflation induced a misperception of investment incentives which in turn led to a misallocation of capital. Reversing that misallocation caused the unermloyment that accompanied a reduction of inflation. With an unindexed tax system, a misallocation of capital can occur during inflation without any misperception. The change in inflation changes relative tax burdens and therefore induces a new allocation of capital. It is interesting also to note that the misallocation of capital caused by the U.S. inflation of the 1970 s was opposite in direction to that predicted by Hayek so that net investment in plant and equipment declined during the decade as a share of GNP.

The effect of the tax system on the economy's transition from a high inflation rate to a low inflation rate is not just a function of its unindexed character. Even a completely indexed tax system would affect the transition process if the reduction in inflation caused some firms to experience a temporary period of accounting losses. The high real interest rates, the depressed level of economic activity, and the reallocation of activity that accompany a reduction in the inflation rate all imply that some firms will have an unprofitable period.

Under conventional tax rules, a firm's incentive to invest is sharply reduced during any period in which it has no taxable profits. The reduced incentive to invest reflects the fact that without taxable profits the firm cannot take advantage of the investment tax credit or the relatively large depreciation allowances that occur during the first few years of an investment's life. The tax savings associated with the depreciation and investinent tax cre- 
dit mist be carried forward to future years and are thereby reduced in value. This implies that the net cost of any investment is increased. In contrast, the positive income from the investment will occur only in the future when the firm expects to be fully taxable. Moreover, since interest payments during the early years of the investment do not reduce concurrent tax liabilities, the effective net interest rate is higher for a nontaxable firm than for a taxable firm.

These distortions arise because the tax system is assymetric in its treatment of gains and losses. If negative tax liabilities were rebated concurrently or could be carried forward with an appropriate rate of interest, this problem would not arise. But existing tax law increases the cyclical sensitivity of investment and makes the impact of monetary policy quite non-neutral among firms and industries.

\section{The Determination of Monetary Policy}

Several years ago, I argued that monetary policy in the 1960 s and 1970s had been too expansionary because the monetary authorities failed to recognize the interaction between inflation and the tax system. ${ }^{2}$ The monetary authorities focused on the interest rate and worried that what they perceived as a high interest rate was discouraging investment and depressing economic activity. In fact, although the nominal interest rate was rising during this period, the real interest rate showed no trend and the real net-of-tax interest rate has fallen substantially. The low real net rate of interest increased

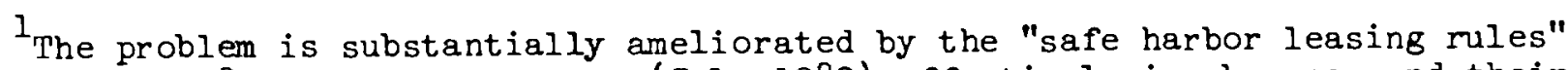
enacted in 1981 but these are now (July 1982) effectively in abeyance and their future is uncertain.

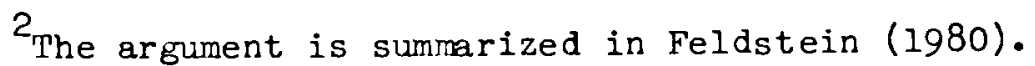


consumption and investment in housing by more than enough to of fset the depressing effect of inflation on investment in plant and equipment.

Since 1979 the Fed has been following a much more monetarist approach in determining its monetrary policy. The gradual deceleration of the money growth rate has become the overriding target of monetary policy. Since interest rates are no longer a fundamental target, the previous mistakes in interpreting the interest rate are no longer relevant.

The future evolution of monetary policy is of course less clear. The future Governors of the Federal Reserve may be less monetarist in their behavior and may revert to targeting interest rates or nominal GNP or some weighted function of inflation, unemployment, and other measures of economic performance. If this happens, how will the fiscal framework influence the future choice of monetary policy?

It is of course possible that the monetary authorities will continue to ignore the fiscal effects of monetary policy and might therefore choose policies that do not achieve their intended results. I want however to examine the implications of assuming to the contrary that the monetary authorities do understand the fiscal consequences of alternative monetary policies and take them into account in their choice of monetary policy. How then might alternative fiscal frameworks affect the choices made by the Fed or urged upon it by the Congress or the administration?

With the tax laws that prevailed in the $1970^{\circ} \mathrm{s}$, a one-time increase in the money stock caused a one-time increase in tax revenue as taxpayers were pushed into higher tax brackets. A sustained increase in the growth rate of the money stock increased tax revenue continually and, by raising the rate of inflation, discouraged investment in plant and equipment. A government eager to 
increase tax revenue in order to eliminate a deficit or to finance increased government spending might therefore encourage an inflationary monetary policy. The enthusiasm for raising revenue in this way would however be tempered and perhaps reversed by recognizing that inflation reduced business investment and therefore the growth of productivity.

The 1981 tax legislation changed both of these fiscal effects. Starting in January 1985, the personal income tax is to be indexed: each year the bracket limits and other nominal amounts in the tax law will be increased in proportion to the recent $r$ ise in the price level. Inflation will therefore no longer push people into higher tax brackets and increase real tax revenue. The 1981 legislation also provides for a much more rapid tax depreciation of plant and equipment. All equipment is now written off over at most five years and with an accelerated schedule equivalent to 150 percent of the five-year declining balance rate. The rapid tax depreciation increases the after-tax return to investment at any inflation rate. Moreover, since depreciation is so rapid, an increase in the rate of inflation reduces the real value of the depreciation allowance by mach less than it did under the old tax rules when much of the equipment was depreciated over 15 years or more. Indeed, companies with moderately high ratios of debt to capital are likely to find that a rise in the rate of inflation actually increases the incentive to invest. How does the 1981 tax legislation alter the likely course of monetary policy? First, indexing the personal tax brackets removes any incentive to use one-time increases in the money stock as a method of raising revenue through bracket creep. Second, since both the "favorable" revenue effect and the adverse investment effect of a sustained monetary expansion are eliminated, the effect on the incentive to pursue an inflationary monetary policy is ambiguous. 
A pessimist might well worry, however, that virtually eliminating one of the major adverse effects of inflation may cause future governments and Federal Reserve Boards to pursue a more inflationary monetary policy.

Future changes in tax rules may make an inflationary monetary policy seem either more or less appealing. One such change is now under active consideration in the Congress. The very large deficits projected for the next several years have induced Congress and the administration to consider alternative ways of increasing tax revenue. One proposal is to repeal the indexing of the personal income tax before it takes effect in 1985. An unindexed tax system would provide a clear incentive to reduce the projected budget deficits by increasing the rate of inflation rather than by the politically painful process of reducing government spending or increasing tax rates explicitly. The knowledge that the inflation will not decrease investment and may actually encourage it would reinforce this temptation to use an expansionary monetary policy.

\section{Concluding Remarks}

My aim in today's lecture has not been to propose or defend any particular theory about the effect of monetary policy on the economy. Instead, my purpose has been the more general one of encouraging macroeconomists and monetary theorists to devote attention to the way that the fiscal framework affects the impact of monetary policy.

The traditional distinction between the specialities of public economics and macroeconomics is undoubtedly a useful one for advancing research in both fields. But the growing role of the public sector and of taxes in particular cannot be ignored in analyzing macroeconomic behavior. 
I hope that remarks today will encourage some of those who hear them or read them later to turn their own attention to this important subject. 


\section{Bibliography}

Auerbach, Alan (1982) "Taxes, Firm Financial Policy and the Cost of Capital: An Empirical Analysis," presented at the NBER-SSRC Oxford Conference on Micro-Data and Public Economics.

Barro, R.J. (1977) "Unanticipated Money Growth and Unemployment in the U.S." American Economic Review: 67, 101-15.

Fama, E. (1975) "Short-term Interest Rates as Predictors of Inflation," American Economic Review, June, 169-82.

Feldstein, M. (1976) "Inflation, Income Taxes, and the Rate of Interest: A Theoretical Analysis," American Economic Review 66, 5, 809-820.

(1980) "Tax Rules and the Mismanagement of Monetary Policy," American Economic Review: 70, 2, 182-86.

(1982) Inflation, Tax Rules and Capital Formation, National Bureau of Economic Research, Chicago: University of Chicago Press.

Feldstein, M., J. Green and E. Sheshinski (1978) "Inflation and Taxes in a Growing Economy with Debt and Equity Finance," Journal of Political Economy: $86,2,553-570$.

Feldstein, M. and J. Poterba (1982) "Unemployment Insurance and Reservation Wages" presented at the NBER-SSRC Oxford conference on "Micro-Data and Public Economics."

Feldstein, M. and L. Summers (1979) "Inflation and the Taxation of Capital Income in the Corporate Sector" National Tax Journal: XXXII, 4, 445-470.

Feldstein, M. and M. Warshawsky, "Inflation, the Menge Formula, and Life Insurance Savings," forthcoming.

Friedman, M. (1969) "The Optimum Supply of Money" The Optimum Supply of Money and Other Essays, Chicago: University of Chicago Press.

Hartinan, D. (1979) "Taxation and the Effects of Inflation on the Real Capital Stock in an Open Economy," International Economic Review: 20, 2, 417-425.

Modigliani, F. and L. Papadenios (1982) "Inflation, Financial Markets, Fiscal Structure, and the Monetarh Mechanism," given at the NBER-EHESS International Seminar on Macroeconomics at the University of Mannheim.

Mundell, R. (1963) "Inflation and Real Interest" Journal of Political Economy: $71,280-83$.

Phelps, E.S. (1973) "Inflation in the Theory of Public Finance," Swedish Journal of Economics: $75,67-82$. 
Poterba, J. (1980) "Inflation, Income Taxes and Owner Occupied Housing," National Bureau of Economic Research Working Paper No. 553.

Sargent, T. (1980) Macroeconomics, New York: Academic Press.

Shiller, R. J. (1980) "Can the Fed Control Real Interest Rates?" in S. Fisher, ed., Rational Expectations and Economic Policy, Chicago: University of Chicago Press.

Stiglitz, J. (1976) "The Corporation Tax" Journal of Public Economics: 5, 303-11.

Summers, L. (1982) "An Asset Price Approach to the Analysis of Cap1tal Income Taxation: Thesis, Harvard University.

Tobin, James (1965) "Money and Economic Growth," Econometrica: 33, 4, 671-84. 